\title{
Potential and clinical utility of stem cells in cardiovascular disease
}

This article was published in the following Dove Press journal:

Stem Cells and Cloning:Advances and Applications

25 March 2010

Number of times this article has been viewed

\section{Korff Krause \\ Carsten Schneider \\ Kai Jaquet \\ Karl-Heinz Kuck}

Hanseatic Heart Center Hamburg, Department of Cardiology, Asklepios Hospital St. Georg, Hamburg, Germany
Correspondence: Korff Krause Asklepios Clinic St. Georg, Cardiology, Lohmülenstrasse 5, 2099 Hamburg, Germany

Email k.krause@asklepios.com

\begin{abstract}
The recent identification of bone marrow-derived adult stem cells and other types of stem cells that could improve heart function after transplantation have raised high expectations. The basic mechanisms have been studied mostly in murine models. However, these experiments revealed controversial results on transdifferentiation vs transfusion of adult stem cells vs paracrine effects of these cells, which is still being debated. Moreover, the reproducibility of these results in precisely translated large animal models is still less well investigated. Despite these weaknesses results of several clinical trials including several hundreds of patients with ischemic heart disease have been published. However, there are no solid data showing that any of these approaches can regenerate human myocardium. Even the effectiveness of cell therapy in these approaches is doubtful. In future we need in this important field of regenerative medicine: i) more experimental data in large animals that are closer to the anatomy and physiology of humans, including data on dose effects, comparison of different cell types and different delivery routes; ii) a better understanding of the molecular mechanisms involved in the fate of transplanted cells; iii) more intensive research on genuine regenerative medicine, applying genetic regulation and cell engineering.
\end{abstract}

Keywords: stem cells, cardiovascular disease

\section{Introduction}

In some vertebrates such as zebrafish and newts cardiac regeneration was documented after severe injury based on division of cardiomyocytes. ${ }^{1,2}$ However, there is not yet proof-of-concept that stem cells can regenerate substantially damaged hearts in humans. Reviewing the literature on the clinical utility of human stem cells in cardiovascular diseases demands controversial considerations. First, clinicians have started studies on bone marrow-derived mononuclear cells (BMC) and myoblasts. Second, clinicians have obviously been influenced by publications in 2001 demonstrating that BMC can repair rodent hearts after experimental myocardial infarction. ${ }^{3,4}$ Neither the intramyocardial injection technique nor the cell type used in these preclinical studies was employed in the first clinical study on BMC therapy in humans with myocardial infarction. ${ }^{5}$ Furthermore although the paper was entitled "Repair of infarcted myocardium", the study was a non-randomized feasibility and safety study, and naturally the data could not provide any evidence for anatomical repair or regeneration influenced by the injected cells. Research on clinical use of stem cell therapy in cardiology was started with inadequate study design and misleading terms and definitions. Many questions have been raised on the validity of stem cell therapy research in cardiology. Even the proof-of-concept of regeneration of damaged hearts

submit your manuscript $\mid$ www.dovepress.con 
is highly controversial, since transdifferentiation of BMC into myocytes ${ }^{3,4}$ could not be reproduced by other groups, and transfusion of myocytes with labeled BMC has been demonstrated, raising the question of misinterpretation of cell transdifferentiation reports. ${ }^{6,7}$ Scientific progress in cell therapy or regenerative medicine is therefore in danger of being delayed. Do basic researchers and clinicians make the wrong studies? It is questionable that the first clinical trials on cell therapy in cardiology started without exact translation of large animal experiments. ${ }^{5,8}$ It would be not the first time that an important therapeutic approach in medical science has been delayed in the beginning, because clinical utility has been demanded too eagerly, as occurred, for example, in the first bone marrow transplantation, trials of gene therapy, and the first human heart transplantation.

In the large field of tissue engineering including heart valve engineering, artificial myocardial tissue, and engineered heart tissue, which so far are based mostly on neonatal rat cardiomyocytes, we like to refer on reviews focusing on this important preclinical work. ${ }^{9,10}$

\section{Embryonic stem cells}

In 1998 human embryonic stem cells (hESC) were first isolated. ${ }^{11}$ These cells have the capacity for unlimited growth and per se transdifferentiation to most of all types of body cells. Mouse ESC had been isolated 17 years before however, there is still no proof that implantation of ESC in humans can cure a single chronic disease. ${ }^{12}$ Despite the controversial interests between religious and political groups there is also concern for scientific reasons. Immunological reactions and the capability of forming teratomas after injection of undifferentiated ESC into the heart have been described. ${ }^{9}{ }^{13-15}$ Although others have not observed these findings, and there is no obvious reason why these experiments did not show teratomas, it would be irresponsible to use undifferentiated ESC in humans. On the other hand, genetic selection of ESC as applied by the Field's group $^{16}$ is capable of creating ES-derived myocytes that have been successfully engrafted in the host heart. Engrafting of these ESCs was documented by immunostaining and alignment and apposition with host myocardial cells. Zandstra et $\mathrm{al}^{17}$ selected myosin + cardiomyocytes out of mouse ESC before transfecting with a fusion gene consisting of cardiac myosin and neomycin resistance genes and neomycin treatment afterwards. Retinoic acid seemed to promote cardiac differentiation. Other genetic selection methods include fluorescent protein expression driven by different cardiac promotors. ${ }^{15,18-20}$ Also, other groups showed improvement of left ventricular ejection fraction by echocardiography after mouse ESC implementation. ${ }^{21-23}$ Engineered ESC has not been shown to form teratomas in these reports.

\section{Induced pluripotent stem cells (iPS)}

Most recently, adult human somatic cells were reprogrammed to pluripotent stem cells by transduction of four transcription factors: Oct3/4, Sox2,Klf4, and c-Myc. ${ }^{24}$ This raises great hope for future regenerative therapy. ${ }^{25}$ Thus, the problems of immunological rejection and embryo destruction can be overcome. The era of real cell replacement therapy could start with the onset of clinical trials after basic researchers and clinicians take account of the lessons learned from cell therapy trials performed. The successful establishment of multipotent adult germline stem cells (maGSCs) from mouse testis has opened another interesting route for true regenerative medicine in cardiovascular diseases. These authors found that maGSCs transplanted into normal hearts of mice were able to proliferate and differentiate. No tumor formation was detected up to 1 month after cell transplantation in these experiments. ${ }^{26,27}$

Cell cycle activity reinduction in cardiomyocytes could be another promising approach. ${ }^{28,29}$

\section{Bone marrow-derived cells}

Starting with the pioneer works of Kocher et al and Orlic et al, ${ }^{3,4}$ since 2001 intramyocardial delivery of bone marrowderived cells have been shown to improve left ventricular function in the ischemically damaged heart. ${ }^{30}$ Several clinical reports indicate the benefit of bone marrow-derived cells (BMC) grafting in patients with acute myocardial infarction (AMI), including CD133+ and CD34+,31-37 bone marrowderived mononuclear stem cells (BMC) and mesenchymal stem cells. Recent reports on intracoronary application of $\mathrm{BMC}$ in humans exhibit controversial results with regard to the improvement of left ventricular function (LVEF). Whereas the TOPCARE-AMI, REPAIR and IACT studies, and others revealed an increase in $\mathrm{LVEF}^{37-40}$ (approx. 3\% increase of LVEF) the studies by Janssens et $\mathrm{al}^{41}$ and Lunde ${ }^{42}$ et al could not reproduce the results.

However, it is difficult to compare the results, because most groups that detected an improvement of LVEF in the cell groups showed impairment of LVEF in the control groups and vice versa. In the BOOST trial the placebo group even increased the LVEF more than the cell group after 18 months. Moreover, different imaging methods (MRI, left ventricular angiography, echocardiography) were applied in the different studies. The date of cell injection in patients after acute myocardial infarction ranged from 3 to 12 days, which makes a huge difference, since the stunning phase after 
revascularization takes place particularly during that time and discrimination between cell effects and discontinuation of the stunning phenomenon is impossible.

Moreover, the clinical studies are not comparable to each other, because different cell types, different isolation and selection techniques, different injection techniques, and different time intervals of cell administration after myocardial infarction are applied in the study protocols. Nonetheless, a meta-analysis of 10 controlled trials enrolling 698 patients after acute myocardial infarction treated with BMC suggest a short-term improvement of LVEF $(2.97 \%){ }^{43}$

Another problem is the shortening of telomeres of BMC which is responsible for decreased replicative capacity. ${ }^{44}$ This phenomenon is also described in endothelial progenitor cells. Moreover, risk factors for cardiovascular diseases correlate with higher rated of in vitro senescence. ${ }^{45}$ This was also observed for cardiac stem cells. ${ }^{46,47}$

\section{Mesenchymal Stem Cells (MSC)}

MSC were discovered and described as bone marrow stromal cells with multipotent potential. ${ }^{47,48}$ Cloned MSCs can differentiate into osteoblasts, adipocytes and chondrocytes. ${ }^{48}$ Even cardiomyocytes were generated from $\mathrm{MSC}^{49}$ in vitro by demethylization with 5-azacytidine. Most studies used undifferentiated MCSs for injection in the damaged heart without differentiation into cardiomyocytes and lack of electromechanical junctions with host cells. ${ }^{50}$ But attenuation of pathological left ventricular remodeling was observed frequently. ${ }^{50-53}$ This is in accordance with other studies using allogeneic MSC. ${ }^{54,55}$ Moreover, MSC are described to induce tolerance which could be responsible for the reduction of graft-versus-host disease, rejection, and modulation of inflammation. ${ }^{56,57}$ These results make MSC interesting cell types for future research, especially for pharmaceutical companies, eg, Osiris Therapeutics.

New ongoing trials like the C-CURE (Cardio3 BioSciences) trial will show new results of intramyocardial delivery of MSC in different dosages in chronic ischemic heart disease. But certainly they will also raise questions about the fate and effectiveness of autologous MSCs.

\section{CDI33+ progenitor cells}

CD133+ progenitor cells are examples for further cell therapy approaches. They can be extracted from the bone marrow and from peripheral blood after leukapheresis and have been shown to contribute to neoangiogenesis. ${ }^{58}$ These progenitor cells seem to have similar positive effects on LVEF as BMC in clinical pilot trials. ${ }^{36,59,60}$ and were used with very few preclinical experimental investigations before. ${ }^{61}$ Large animal experiments are still lacking.

\section{Myoblasts}

Mouse skeletal muscle have been shown to contain a population of precursor cells that can differentiate into beating cells that express cardiomyocyte features. ${ }^{62}$ In humans satellite cells (myoblasts) have been identified which can differentiate into myotubes and improve left ventricular function in animal experiments. ${ }^{63}$ But there is no evidence that these cells can differentiate into cardiomyocytes. ${ }^{13}$

Despite early research on skeletal myoblasts injection in the injured heart ${ }^{63}$ there are several publications that showed that myoblasts can induce proarrhythmogenic effects and are therefore less suitable for clinical trials (paragraph stem cells and arrhythmogeneity). Intramyocardial myoblast injection therapy studies in patients with ischemic cardiomyopathy have been performed mostly during bypass surgery. ${ }^{8,64}$ These trials were conducted with simultaneous coronary reperfusion, so that precise discrimination of the cell injection effect and reperfusion therapy is problematic. This MAGIC trial was stopped because of lack of efficacy.

\section{Adipose derived stem cells}

Adipocyte-derived stem cells are multilineage cells within the stroma vascular fraction of subcutaneous adipose tissue. These cells express surface markers Sca-1 and CD44, but not CD34,CD31, c-kit and CD45. ${ }^{65}$ They have angiogenic potential by secreting of VEGF and HGF. ${ }^{65,66}$ Even cardiomyocyte-like transdifferentiation, in vitro expansion and cardioprotective effects in a mouse-infarction model has been decribed. ${ }^{67}$

\section{Resident myocardial progenitor cells}

Recently, the myocardium - formerly known as a postmitotic tissue - was shown to contain cells with regenerative capacity like other tissues, eg, the skin, bone marrow, intestine. ${ }^{68-70}$ These cardiac stem cells show a reentry into the cell cycle, are clonogenic, self-renewing and multipotent ${ }^{69}$ and capable to regenerate the ischemic myocardium after injection into the border zone of myocardial infarction. Only a small number of these cells are distributed in the atria, the ventricles, and the epicardium. Although, resident cardiac stem cells have been shown to have the potential to differentiate into cardiomyocytes, endothelial, and smooth muscle cells, ${ }^{69,71}$ this occurs at a very low rate. ${ }^{72}$ However, these cardiac stem cells could be isolated and amplified in vitro and therefore are interesting 
candidates for induction of myocardial regeneration. ${ }^{46,73-76}$ Recently, evidence of renewal of human cardiomyocytes ( $1 \%$ annually at the age of 25$)$ was suggested by analysis of carbon-14 integration in human cardiomyocyte DNA, but whether this renewal derives from residential stem cells or cardiomyocyte duplication is not clear. ${ }^{77}$

\section{Paracrine effects of stem cells}

Recently some experimental data have confirmed paracrine effects of stem cells, including angiogenesis and antiapoptotic effects. ${ }^{7,78-81}$ Particularly MSC were investigated and some studies provide evidence for this hypothesis. ${ }^{80,81}$ Dai et $\mathrm{al}^{54}$ and Tang et $\mathrm{al}^{79}$ reported on the enhanced expression of bFGF, SDF1-alpha, and vascular endothelial growth factor (VEGF) accompanied by a downregulation of proapoptotic protein Bax in ischemic myocardium after MSC implantation. Cultured MSC were shown to secret large amounts of angiogenic, antiapoptotic, hepatocyte growth factor and insulin-like growth factor- $1 .^{82}$ It seems that the beneficial effects of MSC are mediated by inhibition of myocardial fibrosis and an increase of angiogenesis and not by transdifferentiation.

Paracrine effects of myoblasts have also been described more recently. ${ }^{83}$ These effects include proangiogenic (PDF), anti-apoptotic (BAG-1, BCL-2) and extracellular matrix remodeling (MMP-2, MMP-7) genes.

It can be assumed that paracrine and angiogenic effects are responsible for the cardioprotective effects on heart function as described in other studies. ${ }^{55,79,80,84,85}$

However, the term "regenerative medicine", if applied specifically to stem cell engraftment and forming new differentiated myocytes, would then be misleading.

\section{Stem cells and arrhythmogenicity}

Safety concerns on the injection of skeletal myoblasts in the chronic ischemic myocardium in clinical studies were raised after documentation of ventricular tachycardias. ${ }^{8,86}$ With regard to the implantation of myoblasts in clinical studies, most ventricular arrhythmic events occurred in the first 4 weeks after cell implantation. In 4 out of 10 patients, ventricular tachycardias occurred between 11 and 22 days, ${ }^{8}$ in similar studies 2 patients out of 21 developed ventricular tachycardias 1 day after coronary artery bypass surgery. ${ }^{64,87}$

Mechanisms of arrhythmia include re-entry, ectopy, and automaticity and potentially the heterogeneity of action potentials of implanted cells. Particularly, implantation of myoblasts has been shown to create an arrhythmogenic substrate, because the implanted cells do not build junctions to the surrounding myocytes. ${ }^{88}$ In these studies myoblasts labeled with Green fluorescent protein were transplanted into rat infarcted myocardium, and differentiated into peculiar "hyperexcitable myotubes with a contractile activity fully independent of neighbouring cardiomyocytes" $" 88$ or were located in cell clusters without connexin expression. ${ }^{89}$ Unfortunately, this analysis was published after performance of clinical trials.

Arrhythmogenicity can be induced through re-entry, automaticity, or triggered activity. All these phenomena can be investigated in large animal models, but publications on this topic in these models are rare.

Only few studies have addressed the electrophysiological properties of transplanted mesenchymal stem cells (MSC), although at present these cells are being studied in several cardiological clinical studies..$^{90}$

Some authors have described that mixtures of MSC and neonatal rat cardiomyocytes exhibit an arrhythmogenic substrate with decreased conduction velocity and easily inducible sustained re-entrant tachycardia, suggesting a proarrhythmic substrate induced by MSC. ${ }^{91,92}$ Chen et al reported that MSC prolonged local activation time and increase the activation time dispersion in a rabbit heart failure model. ${ }^{93}$ Thus, the therapeutic potential of mesenchymal stem cells for myocardial regeneration may be limited by proarrhythmic effects. Moreover, MSC have been described to alter electrophysiological properties in a large animal model. ${ }^{94}$ The authors described a significantly shorter epicardial effective refractory period at all pacing sites 3 months after pigs received MSC intravenously, suggesting a proarrhythmic potential.

Our group evaluated the electrophysiological effects of intramyocardial MSC injection based on a three-dimensional electromechanical mapping technique in vivo. We found no change in conduction velocity and no evidence of a substrate modification towards a higher risk for re-entry tachycardias in the area of injected cells in a post-infarction porcine model. ${ }^{51}$ The results of the study by Mills et al revealed that intravenous MSC infusion (contrary to our study using intramyocardial injection) in a rat acute infarction model even tended to reduce arrhythmia inducibility. ${ }^{95}$ In that study MSC enhanced electrical viability and preserved impulse propagation in the infarct border zone as demonstrated by an optical mapping system. Histologically MSC shows a diffuse engraftment in the host myocardium and expressed connexin.

In clinical studies implanting BMC intramyocardially in patients with chronic ischemic heart disease the incidence of ventricular arrhythmia do not increase. These clinical studies were performed using the NOGA mapping system in patients with myocardial ischemia and no revascularisation option ${ }^{96-98}$ 
showing improvement of regional wall motion and perfusion, and partly of ejection fraction. In the study by Perin et al, 1 patient died 14 weeks after BMC implantation, presumably of sudden cardiac death. ${ }^{98}$ In 20 patients treated with BMC Beeres et al could not find an increased incidence of ventricular arrhythmias in holter monitoring. Corresponding to our preclinical results ${ }^{51} \mathrm{BMC}$ did not alter electrophysiological properties evaluated with electromechanical mapping before and 3 months after cell injection. ${ }^{99}$ Programmed ventricular stimulation was performed only in 1 randomized clinical study which found no differences between the BMC group and the control group. ${ }^{32}$ This study included intracoronary infusion in patients with acute myocardial infarction. In clinical studies infusing BMC, no proarrhythmic effect has yet been described.

For the transplantation of ESC-derived myocytes, further studies should address the arrhythmogenic potential in large animal models. Zhang et al described an increase of arrhythmic potential of embryonic stem cell derived cardiomyocytes. ${ }^{100}$ These cardiomyocytes showed spontaneous activity, prolonged potential duration of action, and easily inducible arrhythmias, and therefore the arrhythmogeneic potential should be carefully investigated.

\section{Cell delivery techniques}

Our group applied intramyocardial injection, because this is by far the most-used delivery technique in preclinical studies. ${ }^{101}$ Moreover we tested efficacy and safety in a large animal model (swine) before starting a trial in humans. ${ }^{52,102}$ It is remarkable that most investigators prefer the intracoronary route, despite the fact that very few animal studies exist on this technique, and most studies have used rodents with intramyocardial cell injections. It is not necessary to use a different delivery route in humans. A simple explanation might be the fact that experimental studies on intracoronary cell injection are expensive due to the need for large animals. In contrast, in humans intracoronary cell delivery is cheaper and less time consuming for interventional cardiologists, because no left ventricular mapping is needed as for intramyocardial cell injection. Moreover the intramyocardial cell delivery technique is more evident, since preclinical experiments using radiolabeled cells indicate that intracoronary infusion results in a myocardial cell residency of $2.6 \%$ compared with $11.0 \%$ using the intramyocardial injection approach. ${ }^{103}$ Therefore, intramyocardial injection may have a more pronounced effect on LV function. ${ }^{104}$ Furthermore, intracoronary cell injection was associated with an increased remote organ engraftment compared with the intramyocardial injection in both an animal model as well as a clinical study. ${ }^{103,105}$

\section{Challenges and future directions}

The rapid translation of preclinical cell-based therapy to restore damaged myocardium has raised questions concerning the best cell type as well as the best delivery route, and the best time of cell injection into the myocardium. All these questions should be addressed and challenged by the Task Force of the European Society of Cardiology, ${ }^{106}$ especially as several new clinical trials are in progress in the United States, Europe and in Asia without standardization of methods (cell harvest, isolation, preparation, delivery, dosage). Pharmacokinetics and pharmacodynamics should be assessed in new drugs as well as in cell therapy. In a review by Murry et al it was pointed out that cell dosages ranged by 6700 fold in the published trials ${ }^{30}$ which underline the need for standardization of cell products. Instead, the Task Force of the ESC stresses a "pragmatic approach to demonstrate clinical efficacy" and does not recommend testing all possible combinations of cell types, number of cells, and so on, in animal models, because it "would take the best part of the century". Moreover, an extension to cardiomyopathy patients was demanded. In view of the controversies outlined in this review, these statements should be questioned.

Reviewing the literature on preclinical investigations, it is remarkable that nearly every cell type tested so far seems to be equipotent for positive effects on $\mathrm{LV}$ function independent of the timing after myocardial infarction, cell numbers and the methods used. ${ }^{30}$ Therefore, experimental models to directly compare different cell types should be evaluated ${ }^{15,51,107}$ to reduce investigator-related bias.

Most reports use rodent models not recognizing that there are major differences between rodents and large mammals in mechanisms of myocardial contraction and ischemia. ${ }^{108} \mathrm{Also}$, there is a wide spectrum of collateral flow between various mammalian species especially for the lack of pre-existing collaterals in the swine heart, but also from a metabolic standpoint in comparision with rodents.

Most clinical studies do not adapt the protocols from experimental studies, making comparsion with preclinical work difficult. Rodent hearts seem to be regenerative. However, the murine heart is more likely to regenerate with a billion cells than a human heart weighing approximately 300 to $500 \mathrm{~g}$. Certainly less than $5 \mathrm{~g}$ of heart tissue would be regenerated with these cell counts applied in clinical studies. None of the clinically used imaging techniques available are sensitive enough to detect the anatomical and functional contribution of $5 \mathrm{~g}$ of myocardial tissue, even if all cell survived, nested and transdifferentiated. Approximately 1 billion cells should transdifferentiate into cardiomyocytes and contract synchronously 
with host myocardium to restore ischemia-induced cardiac damage. ${ }^{30}$ Thus, even the possibility of self-renewing of the human heart ${ }^{109}$ is naturally limited to induce relevant effects in damaged hearts.

What we need for new clinical trials are

i) biology

What is the fate of injected cells in humans? Is there a longterm effect of injected cell in large animal experiments? What dosage of cells is optimal in large animal experiments? Which cells are responsible for which biological effect? We need a better understanding of the molecular mechanisms involved in the fate of transplanted cells.

ii) technical evaluation

What delivery route is most effective? What is the best point of time to deliver cells? What are the dose effects?

iii) intensifying the research on new approaches for stem cell engineering and the research on genuine regenerative medicine applying genetic regulation.

\section{Disclosure}

KK has received educational honoraria from BDS, USA.

\section{References}

1. Poss KD. Getting to the heart of regeneration in zebrafish. Semin Cell Dev Biol. 2007;18:36-45.

2. Borchardt T, Braun T. Cardiovascular regeneration in non-mammalian model systems: what are the differences between newts and man? Thromb Haemost. 2007;98:311-318.

3. Orlic D, Kajstura J, Chimenti S, et al. Bone marrow cells regenerate infarcted myocardium. Nature. 2001;410:701-705.

4. Kocher AA, Schuster MD, Szabolcs MJ, et al. Neovascularization of ischemic myocardium by human bone-marrow-derived angioblasts prevents cardiomyocyte apoptosis, reduces remodeling and improves cardiac function. Nat Med. 2001;7:430-436.

5. Strauer BE, Brehm M, Zeus T, et al. Repair of infarcted myocardium by autologous intracoronary mononuclear bone marrow cell transplantation in humans. Circulation. 2002;106:1913-1918.

6. Murry CE, Soonpaa MH, Reinecke H, et al. Haematopoietic stem cells do not transdifferentiate into cardiac myocytes in myocardial infarcts. Nature. 2004;428:664-668.

7. Ziegelhoeffer T, Fernandez B, Kostin S, et al. Bone marrow-derived cells do not incorporate into the adult growing vasculature. Circ Res. 2004;94:230-238.

8. Menasche P, Hagege AA, Vilquin JT, et al. Autologous skeletal myoblast transplantation for severe postinfarction left ventricular dysfunction. J Am Coll Cardiol. 2003;41:1078-1083.

9. Erdo F, Buhrle C, Blunk J, et al. Host-dependent tumorigenesis of embryonic stem cell transplantation in experimental stroke. $J$ Cereb Blood Flow Metab. 2003;23:780-785.

10. Zimmermann WH, Didie M, Doker S, et al. Heart muscle engineering: an update on cardiac muscle replacement therapy. Cardiovasc Res. 2006;71:419-429.

11. Thomson JA, Itskovitz-Eldor J, Shapiro SS, et al. Embryonic stem cell lines derived from human blastocysts. Science. 1998;282:1145-1147.

12. Evans MJ, Kaufman MH. Establishment in culture of pluripotential cells from mouse embryos. Nature. 1981;292:154-156.

13. Laflamme MA, Murry CE. Regenerating the heart. Nat Biotechnol. 2005;23:845-856.
14. Riess P, Molcanyi M, Bentz K, et al. Embryonic stem cell transplantation after experimental traumatic brain injury dramatically improves neurological outcome, but may cause tumors. J Neurotrauma. 2007;24:216-225.

15. Kolossov E, Bostani T, Roell W, et al. Engraftment of engineered ES cell-derived cardiomyocytes but not BM cells restores contractile function to the infarcted myocardium. J Exp Med. 2006;203:2315-2327.

16. Klug MG, Soonpaa MH, Koh GY, Field LJ. Genetically selected cardiomyocytes from differentiating embronic stem cells form stable intracardiac grafts. J Clin Invest. 1996;98:216-224.

17. Zandstra PW, Bauwens C, Yin T, et al. Scalable production of embryonic stem cell-derived cardiomyocytes. Tissue Eng. 2003;9:767-778.

18. Hidaka K, Lee JK, Kim HS, et al. Chamber-specific differentiation of Nkx2.5-positive cardiac precursor cells from murine embryonic stem cells. Faseb J. 2003;17:740-742.

19. Kolossov E, Lu Z, Drobinskaya I, et al. Identification and characterization of embryonic stem cell-derived pacemaker and atrial cardiomyocytes. Faseb J. 2005;19:577-579.

20. Meyer N, Jaconi M, Landopoulou A, Fort P, Puceat M. A fluorescent reporter gene as a marker for ventricular specification in ES-derived cardiac cells. FEBS Lett. 2000;478:151-158.

21. Min JY, Yang Y, Converso KL, et al. Transplantation of embryonic stem cells improves cardiac function in postinfarcted rats. J Appl Physiol. 2002;92:288-296

22. Min JY, Yang Y, Sullivan MF, et al. Long-term improvement of cardiac function in rats after infarction by transplantation of embryonic stem cells. J Thorac Cardiovasc Surg. 2003;125:361-369.

23. Hodgson DM, Behfar A, Zingman LV, et al. Stable benefit of embryonic stem cell therapy in myocardial infarction. Am J Physiol Heart Circ Physiol. 2004;287:H471-H479.

24. Takahashi K, Tanabe K, Ohnuki M, et al. Induction of pluripotent stem cells from adult human fibroblasts by defined factors. Cell. 2007; 131:861-872.

25. Tanaka T, Tohyama S, Murata M, et al. In vitro pharmacologic testing using human induced pluripotent stem cell-derived cardiomyocytes. Biochem Biophys Res Commun. 2009;385:497-502.

26. Guan K, Wagner S, Unsold B, et al. Generation of functional cardiomyocytes from adult mouse spermatogonial stem cells. Circ Res. 2007; 100:1615-1625.

27. Guan K, Nayernia K, Maier LS, Wagner S, et al. Pluripotency of spermatogonial stem cells from adult mouse testis. Nature. 2006;440:1199-1203.

28. Field LJ. Modulation of the cardiomyocyte cell cycle in genetically altered animals. Ann NY Acad Sci. 2004;1015:160-170.

29. Campa VM, Gutierrez-Lanza R, Cerignoli F, et al. Notch activates cell cycle reentry and progression in quiescent cardiomyocytes. $J$ Cell Biol. 2008;183:129-141.

30. Murry CE, Reinecke H, Pabon LM. Regeneration gaps: observations on stem cells and cardiac repair. J Am Coll Cardiol. 2006;47:1777-1785.

31. Assmus B, Honold J, Schachinger V, et al. Transcoronary transplantation of progenitor cells after myocardial infarction. $N$ Engl J Med. 2006;355:1222-1232.

32. Meyer GP, Wollert KC, Lotz J, et al. Intracoronary bone marrow cell transfer after myocardial infarction: eighteen months' follow-up data from the randomized, controlled BOOST (BOne marrOw transfer to enhance ST-elevation infarct regeneration) trial. Circulation. 2006; 113:1287-1294.

33. Chen SL, Fang WW, Ye F, et al. Effect on left ventricular function of intracoronary transplantation of autologous bone marrow mesenchymal stem cell in patients with acute myocardial infarction. Am J Cardiol. 2004;94:92-95.

34. Schachinger V, Erbs S, Elsasser A, et al. Improved clinical outcome after intracoronary administration of bone-marrow-derived progenitor cells in acute myocardial infarction: final 1-year results of the REPAIRAMI trial. Eur Heart J. 2006;27:2775-2783.

35. Assmus B, Walter DH, Lehmann R, et al. Intracoronary infusion of progenitor cells is not associated with aggravated restenosis development or atherosclerotic disease progression in patients with acute myocardial infarction. Eur Heart J. 2006;27:2985-2995. 
36. Bartunek J, Vanderheyden M, Vandekerckhove B, et al. Intracoronary injection of CD133-positive enriched bone marrow progenitor cells promotes cardiac recovery after recent myocardial infarction: feasibility and safety. Circulation. 2005;112:178-183.

37. Schachinger V, Assmus B, Britten MB, et al. Transplantation of progenitor cells and regeneration enhancement in acute myocardial infarction: final one-year results of the TOPCARE-AMI Trial. J Am Coll Cardiol. 2004;44:1690-1699.

38. Assmus B, Schachinger V, Teupe C, et al. Transplantation of Progenitor Cells and Regeneration Enhancement in Acute Myocardial Infarction (TOPCARE-AMI). Circulation. 2002;106:3009-3017.

39. Fernandez-Aviles F, San Roman JA, Garcia-Frade J, et al. Experimental and clinical regenerative capability of human bone marrow cells after myocardial infarction. Circ Res. 2004;95:742-748.

40. Strauer BE, Brehm M, Zeus T, et al. Regeneration of human infarcted heart muscle by intracoronary autologous bone marrow cell transplantation in chronic coronary artery disease: the IACT Study. J Am Coll Cardiol. 2005;46:1651-1658.

41. Janssens S, Dubois C, Bogaert J, et al. Autologous bone marrow-derived stem-cell transfer in patients with ST-segment elevation myocardial infarction: double-blind, randomised controlled trial. Lancet. 2006; 367:113-121.

42. Lunde $\mathrm{K}$, Solheim $\mathrm{S}$, Aakhus $\mathrm{S}$, et al. Intracoronary injection of mononuclear bone marrow cells in acute myocardial infarction. $N$ Engl J Med 2006;355:1199-1209.

43. Lipinski MJ, Biondi-Zoccai GG, Abbate A, et al. Impact of intracoronary cell therapy on left ventricular function in the setting of acute myocardial infarction: a collaborative systematic review and meta-analysis of controlled clinical trials. J Am Coll Cardiol. 2007;50: 1761-1767.

44. Anversa P, Kajstura J, Leri A, Bolli R. Life and death of cardiac stem cells: a paradigm shift in cardiac biology. Circulation. 2006;113: 1451-1463.

45. Hill JM, Zalos G, Halcox JP, et al. Circulating endothelial progenitor cells, vascular function, and cardiovascular risk. $N$ Engl J Med. 2003; 348:593-600.

46. Urbanek K, Torella D, Sheikh F, et al. Myocardial regeneration by activation of multipotent cardiac stem cells in ischemic heart failure. Proc Natl Acad Sci U S A. 2005;102:8692-8697.

47. Caplan AI. Mesenchymal stem cells. J Orthop Res. 1991;9:641-650.

48. Pittenger MF, Mackay AM, Beck SC, et al. Multilineage potential of adult human mesenchymal stem cells. Science. 1999;284:143-147.

49. Hakuno D, Fukuda K, Makino S, et al. Bone marrow-derived regenerated cardiomyocytes (CMG Cells) express functional adrenergic and muscarinic receptors. Circulation. 2002;105:380-386.

50. Shake JG, Gruber PJ, Baumgartner WA, et al. Mesenchymal stem cell implantation in a swine myocardial infarct model: engraftment and functional effects. Ann Thorac Surg. 2002;73:1919-1925; discussion 1926.

51. Krause K, Schneider C, Lange C, et al. Endocardial electrogram analysis after intramyocardial injection of mesenchymal stem cells in the chronic ischemic myocardium pacing. Clin Electrophysiol. 2009;32:1319-1328.

52. Schneider C, Krause K, Jaquet K, et al. Intramyocardial transplantation of bone marrow-derived stem cells: ultrasonic strain rate imaging in a model of hibernating myocardium. J Card Fail. 2008;14: 861-872.

53. Amado LC, Saliaris AP, Schuleri KH, et al. Cardiac repair with intramyocardial injection of allogeneic mesenchymal stem cells after myocardial infarction. Proc Natl Acad Sci U S A. 2005;102:11474-11479.

54. Dai W, Hale SL, Martin BJ, et al. Allogeneic mesenchymal stem cell transplantation in postinfarcted rat myocardium: short- and long-term effects. Circulation. 2005;112:214-223.

55. Kinnaird T, Stabile E, Burnett MS, et al. Local delivery of marrowderived stromal cells augments collateral perfusion through paracrine mechanisms. Circulation. 2004;109:1543-1549.

56. Aggarwal S, Pittenger MF. Human mesenchymal stem cells modulate allogeneic immune cell responses. Blood. 2005;105:1815-1822.
57. Le Blanc K. Immunomodulatory effects of fetal and adult mesenchymal stem cells. Cytotherapy. 2003;5:485-489.

58. Reyes M, Dudek A, Jahagirdar B, Koodie L, Marker PH, Verfaillie CM. Origin of endothelial progenitors in human postnatal bone marrow. J Clin Invest. 2002;109:337-346.

59. Manginas A, Goussetis E, Koutelou M, et al. Pilot study to evaluate the safety and feasibility of intracoronary CD133(+) and CD133(-) CD34(+) cell therapy in patients with nonviable anterior myocardial infarction. Catheter Cardiovasc Interv. 2007;69:773-781.

60. Stamm C, Westphal B, Kleine HD, et al. Autologous bone-marrow stem-cell transplantation for myocardial regeneration. Lancet. 2003; 361:45-46.

61. Agbulut O, Vandervelde S, Al Attar N, et al. Comparison of human skeletal myoblasts and bone marrow-derived CD133+ progenitors for the repair of infarcted myocardium. J Am Coll Cardiol. 2004;44: $458-463$.

62. Winitsky SO, Gopal TV, Hassanzadeh S, et al. Adult murine skeletal muscle contains cells that can differentiate into beating cardiomyocytes in vitro. PLoS Biol. 2005;3:e87.

63. Dowell JD, Rubart M, Pasumarthi KB, Soonpaa MH, Field LJ. Myocyte and myogenic stem cell transplantation in the heart. Cardiovasc Res. 2003;58:336-350.

64. Herreros J, Prosper F, Perez A, et al. Autologous intramyocardial injection of cultured skeletal muscle-derived stem cells in patients with non-acute myocardial infarction. Eur Heart J. 2003;24: 2012-2020.

65. Planat-Benard V, Silvestre JS, Cousin B, et al. Plasticity of human adipose lineage cells toward endothelial cells: physiological and therapeutic perspectives. Circulation. 2004;109:656-663.

66. Planat-Benard V, Menard C, Andre M, et al. Spontaneous cardiomyocyte differentiation from adipose tissue stroma cells. Circ Res. 2004; 94:223-229.

67. Leobon B, Roncalli J, Joffre C, et al. Adipose-derived cardiomyogenic cells: in vitro expansion and functional improvement in a mouse model of myocardial infarction. Cardiovasc Res. 2009;83:757-767.

68. Beltrami AP, Urbanek K, Kajstura J, et al. Evidence that human cardiac myocytes divide after myocardial infarction. $N$ Engl J Med. 2001;344:1750-1757.

69. Beltrami AP, Barlucchi L, Torella D, et al. Adult cardiac stem cells are multipotent and support myocardial regeneration. Cell. 2003;114: $763-776$.

70. Winter EM, Grauss RW, Hogers B, et al. Preservation of left ventricular function and attenuation of remodeling after transplantation of human epicardium-derived cells into the infarcted mouse heart. Circulation. 2007;116:917-927.

71. Oh H, Bradfute SB, Gallardo TD, et al. Cardiac progenitor cells from adult myocardium: homing, differentiation, and fusion after infarction. Proc Natl Acad Sci U S A. 2003;100:12313-12318.

72. Hsieh PC, Segers VF, Davis ME, et al. Evidence from a genetic fatemapping study that stem cells refresh adult mammalian cardiomyocytes after injury. Nat Med. 2007;13:970-974.

73. Messina E, De Angelis L, Frati G, et al. Isolation and expansion of adult cardiac stem cells from human and murine heart. Circ Res. 2004;95:911-921.

74. Barile L, Chimenti I, Gaetani R, et al. Cardiac stem cells: isolation, expansion and experimental use for myocardial regeneration. Nat Clin Pract Cardiovasc Med. 2007;4 Suppl 1:S9-S14.

75. Urbanek K, Rota M, Cascapera S, et al. Cardiac stem cells possess growth factor-receptor systems that after activation regenerate the infarcted myocardium, improving ventricular function and long-term survival. Circ Res. 2005;97:663-673.

76. Torella D, Ellison GM, Mendez-Ferrer S, Ibanez B, Nadal-Ginard B. Resident human cardiac stem cells: role in cardiac cellular homeostasis and potential for myocardial regeneration. Nat Clin Pract Cardiovasc Med. 2006;3 Suppl 1:S8-S13.

77. Bergmann O, Bhardwaj RD, Bernard S, et al. Evidence for cardiomyocyte renewal in humans. Science. 2009;324:98-102. 
78. Kubal C, Sheth K, Nadal-Ginard B, Galinanes M. Bone marrow cells have a potent anti-ischemic effect against myocardial cell death in humans. J Thorac Cardiovasc Surg. 2006;132:1112-1118.

79. Tang YL, Zhao Q, Qin X, et al. Paracrine action enhances the effects of autologous mesenchymal stem cell transplantation on vascular regeneration in rat model of myocardial infarction. Ann Thorac Surg. 2005; 80:229-236; discussion 236-227.

80. Gnecchi M, He H, Liang OD, et al. Paracrine action accounts for marked protection of ischemic heart by Akt-modified mesenchymal stem cells. Nat Med. 2005;11:367-368.

81. Gnecchi M, He H, Noiseux N, et al. Evidence supporting paracrine hypothesis for Akt-modified mesenchymal stem cell-mediated cardiac protection and functional improvement. Faseb J. 2006;20:661-669.

82. Nagaya N, Fujii T, Iwase T, et al. Intravenous administration of mesenchymal stem cells improves cardiac function in rats with acute myocardial infarction through angiogenesis and myogenesis. Am J Physiol Heart Circ Physiol. 2004;287:H2670-H2676.

83. Perez-Ilzarbe M, Agbulut O, Pelacho B, et al. Characterization of the paracrine effects of human skeletal myoblasts transplanted in infarcted myocardium. Eur J Heart Fail. 2008;10:1065-1072.

84. Kamihata $\mathrm{H}$, Matsubara $\mathrm{H}$, Nishiue T, et al. Implantation of bone marrow mononuclear cells into ischemic myocardium enhances collateral perfusion and regional function via side supply of angioblasts, angiogenic ligands, and cytokines. Circulation. 2001;104:1046-1052.

85. Zeng $\mathrm{L}, \mathrm{Hu} \mathrm{Q}$, Wang $\mathrm{X}$, et al. Bioenergetic and functional consequences of bone marrow-derived multipotent progenitor cell transplantation in hearts with postinfarction left ventricular remodeling. Circulation. 2007;115:1866-1875.

86. Menasche P, Hagege A, Scorsin M, et al. Autologous skeletal myoblast transplantation for cardiac insufficiency. First clinical case. Arch Mal Coeur Vaiss. 2001;94:180-182.

87. Siminiak T, Burchardt P, Kurpisz M. Postinfarction heart failure: surgical and trans-coronary-venous transplantation of autologous myoblasts. Nat Clin Pract Cardiovasc Med. 2006;3 Suppl 1:S46-S51.

88. Leobon B, Garcin I, Menasche P, Vilquin JT, Audinat E, Charpak S. Myoblasts transplanted into rat infarcted myocardium are functionally isolated from their host. Proc Natl Acad Sci U S A. 2003;100: 7808-7811.

89. Fouts K, Fernandes B, Mal N, Liu J, Laurita KR. Electrophysiological consequence of skeletal myoblast transplantation in normal and infarcted canine myocardium. Heart Rhythm. 2006;3:452-461.

90. Katritsis DG, Sotiropoulou PA, Karvouni E, et al. Transcoronary transplantation of autologous mesenchymal stem cells and endothelial progenitors into infarcted human myocardium. Catheter Cardiovasc Interv. 2005;65:321-329.

91. Chang MG, Tung L, Sekar RB, et al. Proarrhythmic potential of mesenchymal stem cell transplantation revealed in an in vitro coculture model. Circulation. 2006;113:1832-1841.

92. Beeres SL, Atsma DE, van der Laarse A, et al. Human adult bone marrow mesenchymal stem cells repair experimental conduction block in rat cardiomyocyte cultures. J Am Coll Cardiol. 2005;46:1943-1952.

93. Chen M, Fan ZC, Liu XJ, et al. Effects of autologous stem cell transplantation on ventricular electrophysiology in doxorubicin-induced heart failure. Cell Biol Int. 2006;30:576-582.
94. Price MJ, Chou CC, Frantzen M, et al. Intravenous mesenchymal stem cell therapy early after reperfused acute myocardial infarction improves left ventricular function and alters electrophysiologic properties. Int $J$ Cardiol. 2006;111:231-239.

95. Mills WR, Mal N, Kiedrowski MJ, et al. Stem cell therapy enhances electrical viability in myocardial infarction. $J$ Mol Cell Cardiol. 2007;42:304-314

96. Fuchs S, Kornowski R, Weisz G, et al. Safety and feasibility of transendocardial autologous bone marrow cell transplantation in patients with advanced heart disease. Am J Cardiol. 2006;97:823-829.

97. Tse HF, Thambar S, Kwong YL, et al. Safety of catheter-based intramyocardial autologous bone marrow cells implantation for therapeutic angiogenesis. Am J Cardiol. 2006;98:60-62.

98. Perin EC, Dohmann HF, Borojevic R, et al. Improved exercise capacity and ischemia 6 and 12 months after transendocardial injection of autologous bone marrow mononuclear cells for ischemic cardiomyopathy. Circulation. 2004;110:II213-II218.

99. Beeres SL, Zeppenfeld K, Bax JJ, et al. Electrophysiological and arrhythmogenic effects of intramyocardial bone marrow cell injection in patients with chronic ischemic heart disease. Heart Rhythm. 2007;4:257-265.

100. Zhang YM, Hartzell C, Narlow M, Dudley SC Jr. Stem cell-derived cardiomyocytes demonstrate arrhythmic potential. Circulation. 2002;106:1294-1299.

101. Krause K, Jaquet K, Schneider C, et al. Percutaneous intramyocardial stem cell injection in patients with acute myocardial infarction: firstin-man study. Heart. 2009;95:1145-1152.

102. Schneider C, Jaquet K, Geidel S, et al. Transplantation of bone marrowderived stem cells improves myocardial diastolic function: strain rate imaging in a model of hibernating myocardium. $J$ Am Soc Echocardiogr. 2009.

103. Hou D, Youssef EA, Brinton TJ, et al. Radiolabeled cell distribution after intramyocardial, intracoronary, and interstitial retrograde coronary venous delivery: implications for current clinical trials. Circulation. 2005;112:I150-I156.

104. Perin EC, Silva GV, Assad JA, et al. Comparison of intracoronary and transendocardial delivery of allogeneic mesenchymal cells in a canine model of acute myocardial infarction. J Mol Cell Cardiol. 2008;44:486-495.

105. Hofmann M, Wollert KC, Meyer GP, et al. Monitoring of bone marrow cell homing into the infarcted human myocardium. Circulation. 2005; 111:2198-2202.

106. Bartunek J, Dimmeler S, Drexler H, et al. The consensus of the task force of the European Society of Cardiology concerning the clinical investigation of the use of autologous adult stem cells for repair of the heart. Eur Heart J. 2006;27:1338-1340.

107. van der Bogt KE, Sheikh AY, Schrepfer S, et al. Comparison of different adult stem cell types for treatment of myocardial ischemia. Circulation. 2008;118:S121-S129.

108. Hughes GC, Post MJ, Simons M, Annex BH. Translational physiology: porcine models of human coronary artery disease: implications for preclinical trials of therapeutic angiogenesis. J Appl Physiol. 2003; 94:1689-1701.

109. Quaini F, Urbanek K, Beltrami AP, et al. Chimerism of the transplanted heart. $N$ Engl J Med. 2002;346:5-15.
Stem Cells and Cloning: Advances and Applications

\section{Publish your work in this journal}

Stem Cells and Cloning: Advances and Applications is an international, peer-reviewed, open access journal. Areas of interest in stem cell research include: Embryonic cell stems; Adult stem cells; Blastocysts; Cordblood stem cells; Stem cell transformation and culture; Therapeutic cloning; Umbilical cord blood and bone marrow cells; Laboratory,

\section{Dovepress}

animal and human therapeutic studies; Philosophical and ethical issues related to stem cell research. This journal is indexed on CAS. The manuscript management system is completely online and includes a quick and fair peer-review system. Visit http://www.dovepress.com/ testimonials.php to read real quotes from published authors. 